Espaço Aberto | Open Space

\title{
How Brazilian social scientists responded to the pandemic
}

Como as cientistas sociais brasileiras reagiram à pandemia

\author{
Rodrigo Toniol' \\ https://orcid.org/0000-0002-1169-5253 \\ rodrigo.toniol@gmail.com \\ Miriam Grossi" \\ https://orcid.org/0000-0002-4399-6544 \\ miriamgrossi@gmail.com \\ ' Universidade Federal do Rio de Janeiro - Rio de Janeiro, RJ, Brazil \\ " Universidade Federal de Santa Catarina - Florianópolis, SC, Brazil
}




\begin{abstract}
In this article, we propose a critical and situational assessment of Brazilian social scientists' production on the COVID pandemic. We take stock of production within the context of the pandemic, yet also go further to sketch out some of the general characteristics of scientific production within Brazilian social sciences. Our major reference is a publication that, from within the social sciences, initiated an entire movement toward public reflections on the pandemic: the Social Scientists and Coronavirus Bulletin. It was published on a daily basis under the auspices of the National Association of Graduate Studies and Research in Social Sciences (Anpocs), in partnership with other scientific associations. We argue that social sciences' reaction to the pandemic both engages and contrasts with the tradition of debates on health within our disciplines. We also offer a classification scheme for the wide range of texts written "in the heat of the moment" by social scientists, in their quest to understand the pandemic and its effects. Finally, we offer a brief and descriptive analysis of the Bulletin's texts characteristics, unfolding into a larger discussion of the institutional transformations that have marked Brazilian social sciences.
\end{abstract}

Keywords: social sciences; scientific policy; pandemic; health.

\title{
Resumo
}

Neste artigo propomos uma avaliação crítica e situacional sobre a produção das cientistas sociais brasileiras sobre a pandemia de Covid-19. Trata-se de um balanço situado pelo fenômeno da pandemia, mas, procuramos explicitar, também indicativo de características mais gerais da produção científica das ciências sociais brasileiras. Para tanto, tomamos como referência a publicação que iniciou o movimento de reflexões públicas das ciências sociais no Brasil sobre a pandemia, o Boletim Cientistas Sociais e Coronavírus publicado diariamente pela Associação Nacional de Pós-Graduação e Pesquisa em Ciências Sociais (Anpocs) em parceria com outras associações científicas (ABA, SBS, ABCP e ACSRM). Destacamos como essa reação à pandemia dialoga e contrasta com a tradição dos debates que articulam as ciências sociais com a área da saúde. Também oferecemos uma reflexão geral e um esquema de classificação do amplo conjunto de textos deste boletim, escritos "no calor da hora" por cientistas sociais na tentativa de compreender a pandemia e seus efeitos. Realizamos, por fim, uma análise descritiva das características dos textos do boletim, desdobrando-as em apontamentos mais amplos, capazes de indicar transformações que marcaram institucionalmente as ciências sociais no Brasil na segunda década do século XX.

Palavras-chave: ciências sociais; política científica; pandemia; saúde. 


\section{Introduction}

This article discusses what we refer to as an experience in engaged intellectual production toward building an understanding of the COVID-19 pandemic in Brazil. It took the concrete shape of a publication that was made available through the Anpocs website, under the title of the Social Scientists and Coronavirus Bulletin (Boletim Cientistas Sociais e o Coronavírus, 2020). During the period spanning March - July of 2020, the Bulletin came out on a daily basis, under the joint sponsorship of the National Association of Post-graduate Programs and Research in the Social Sciences (Associação Nacional de Pós-Graduação e Pesquisa em Ciências Sociais - Anpocs) and its member institutions, the Brazilian Anthropological Association (Associação Brasileira de Antropologia - ABA), the Brazilian Political Science Association (Associação Brasileira de Ciência de Política - ABCP), Brazilian Sociological Association (Sociedade Brasileira de Sociologia-SBS) and the Mercosul Association of Social Scientists for the Study of Religion (Associação dos Cientistas Sociais da Religião do Mercosul - ACSRM).

As the editors of the Bulletin, we reflect here on the meaning that this editorial project has for Brazilian social sciences. As its publication began on the first weekend of social isolation in Brazil, it both initiated and legitimated a movement of public reflections, on the part of social scientists, on the pandemic in Brazil.

Throughout the year 2020, the Bulletin became a significant reference that went beyond the disciplines of sociology, anthropology and political science. It was replicated by the Brazilian Society for the Progress of Science (Sociedade Brasileira para o Progresso da Ciência - SBPC) and by other scientific associations, used as teaching material in the classroom and to provide supporting texts to commissions for the combat of coronavirus within several universities. It also became an instrument for foreign researchers wanting to understand the impacts that COVID-19 was having in Brazil under the Bolsonaro administration. ${ }^{1}$

1 See examples brought out by participants in the CLO1Colloquium: Social Sciences and the Coronavirus Bulletin - The reaction of the Brazilian Social Sciences, held as part of the 44th Annual Meeting of the Anpocs in December of 2020, with participants Rodrigo Toniol (UFRJ), Felipe Fernandes (UFBA), Matheus Zago (Würzburg University) and Pamela Laurentina (UEPI). 
In this article we provide a critical and situational analysis of the intellectual field of the social sciences in Brazil, based on articles that were published in the Social Scientists and Coronavirus Bulletin, between March and July of 2020. This is a moment of taking stock that takes its contours from the event of the pandemic itself. Yet, as we intend to show here, it also casts light on the more general characteristics of social scientists, and on the scientific production of this field of knowledge in its interdisciplinary interfaces.

The Social Scientists and Coronavirus Bulletin brought together a set of articles by social scientists and scholars from other areas of the Human Sciences that were written "at the heat of the moment", that is, with the emotional intensity that marked the early days of the pandemic. In an accessible language and limited to a mere 1000 words, contributions covered a variety of gazes from the social sciences, as they confronted events and situations pertaining to the context of social isolation and the need to face up to a global pandemic. Articles sought to analyze the impacts that COVID-19 wrought, starting from the date of its recorded arrival in Brazil, in February of 2020, and as it made its way into different places, social groups and research fields throughout the country. ${ }^{2}$

We wrote a first version of the present introduction in August, 2020, as we were bringing the Bulletin project to a close. The second version, the one we offer here, returns to the major questions of the earlier text, yet moves further in reflections on how theoretical work in Brazilian social sciences impacted public opinion and the construction of scientific interpretations of the global pandemic. Now, in February of 2021, we are still struggling with the pandemic and have no real end in sight - largely due to the lack of governmental planning, whether in terms of pandemic prevention, field hospitals and treatment services or of acquisition, production, distribution and application of vaccines.

Over the last six months, predictions made by a significant part of the worldwide social science community in the world during the first few months of the pandemic have concretized; ${ }^{3}$ furthermore, the event itself has brought

2 Throughout the text, we will use just the word Bulletin as a shorthand reference to this initiative.

3 We award special mention to the conferences given by Michel Wieviorka (2020) and by Nísia Trindade Lima (2020), at the 44th Annual Meeting of the Anpocs, in December, 2020. The talks are available online (see Encontro Anual da Anpocs, 2020). 
about major transformations in global social life and will most likely continue to do so over the decades that follow. ${ }^{4}$ After a full year of pandemic and compulsory social isolation, there is now a vast quantity of production in the human sciences that analyzes the entropic process that this critical event has wrought worldwide.

Much has changed since the period in which the Bulletin was coming out every day. In July of 2020, we were moving close to the 100,000 death mark, already looming large as one of the most serious social and humanitarian tragedies in the history of the country. The death toll continued to rise and now, at the end of February, 2021, we are at over 250,000 pandemic deaths, having peaked at a daily toll of 1,500 per day. Although this is in itself a daunting number, researchers argue that the given numbers fall short of reality, due to underreporting and the fact that many deaths that are linked to COVID-19 are not recorded as such. Furthermore, we are now living the nightmare of the "Brazilian variant" of the virus, the strain that was responsible for the second huge wave of deaths in Manaus and the whole Amazon region and has now reached all the states in the country, pushing the national health system to the brink of collapse.

We have divided the rest of our text into three different parts. In the first section, we weave considerations on the overwhelming and inescapable nature of the impact of the pandemic on production in the social sciences. Explored from a wide range of perspectives, the pandemic as a theme imposed itself on researchers of different disciplines - Anthropology, Sociology, Political Science - consolidating a relatively unprecedented phenomenon in Brazil, in the sense of such considerable attention directed toward just one event. We explore this phenomenon in all its singularity, capturing the similarities and contrasts of its diverse processes. We seek an understanding of how the social sciences as a whole turned their attention to one specific event, in the field of public health, plunging into its multiple

4 By the time the present version of our text is published in the journal Horizontes Antropológicos, the context is likely to have undergone further shift, as one of the defining traits of the current pandemic is the constant reconfiguration of the social life that it has affected, whether in its public or private dimensions. 
facets. Thus, we give particular salience to the way this situation converses and contrasts with more established traditions in social science approaches to the field of health.

In the second part of this paper, we propose a classificatory framework for a wide set of texts - writings by social scientists of different generations and fields of knowledge, with distinct analyses of the pandemic and its effects. Although based on articles published in the Social Scientists and Coronavirus Bulletin, we consider our classificatory scheme to be applicable to many other similar publications. It renders a picture pertinent to similar types of activities that sprouted up over the course of the first year of the pandemic in Brazil.

In the third section, we engage in a more descriptive analysis of the professional status of the authors of texts published in the Bulletin, and go on to make broader considerations that provide a picture of how the field of the social sciences is configured in Brazil today. We highlight transformations that have marked the institutional characteristics of this scientific field, such as its capillarization to universities outside major cities and throughout the entire country. This dissemination process was carried out through robust public policies of investment in post-graduate programs and the creation of new public universities during the administrations of Presidents Lula and Dilma Rousseff (2003-2016), allowing for the rapid absorption of young PhDs trained in the three major areas of Brazilian social science.

It is not our purpose here to offer theoretical or ethnographic contributions that undertake the study of the pandemic as a phenomenon. Analyses of this sort may be found in other articles in this issue of Horizontes Antropológicos. Our purpose here has been to take stock of the social sciences as a field of study, taking its scholarly production as our focus. The writers whose work we consider here are not necessarily specialists in pandemic events nor in issues of health; rather, they are intellectuals who have felt compelled to reflect on the pandemic because of the way it burst into everyday life, taking its toll on personal and professional lives. COVID-19 had a direct impact on academic practices of teaching and transmission of knowledge, demanding immediate passage from physical encounters to virtual ones. It also affected all fields of research, and this is reflected in the articles published in the Bulletin. 
Our quest here has been to build a meta-analytic analysis of a particular historical moment. We are also reminded of the fact that it was produced during the pandemic, and that our efforts in putting it together illustrate one of the major characteristics of the Brazilian social sciences, that is, their ability to mobilize both theoretically and practically in the face of pressing political moments. Furthermore, this article will also constitute a historical record of the ways in which social scientists reacted, during the year 2020, in the face of the COVID-19 pandemic in Brazil. We leave our testimony here as an illustration and an archive, so that future generations understand how we acted and how our thinking unfolded in the face of this extremely dramatic moment of social life in Brazil and the world.

\section{The pandemic through the gaze of the social sciences}

\section{Pandemic Kaleidoscope}

Almost 12 months after the start of the COVID-19 pandemic in Brazil, we have little doubt that Total Social Fact, Marcel Mauss's (1974) landmark concept, is the most comprehensive and appropriate point of departure for our understanding of the impact that the circulation of the virus had on public and private life in the country, and for capturing the subject's overwhelming dominion in recent debates within the Brazilian social sciences. While at first we looked to explanations and analyses provided by colleagues in the field of the study of epidemics, viruses and health, we soon realized, from the scope of articles received for publication in the Bulletin, that concerns regarding the coronavirus went way beyond the field of health.

Similarly undeniable is the importance of the use of the category critical event, proposed by Veena Das (1995) as crucial to our thinking on the pandemic as a global event with local effects, and on the role of the State in confronting the social effects of a virus over the population as a whole. Lock down, emergency aid, return to school, need for economic recovery, vaccine purchase and rollout were some of the measures on the part of the State that received wide media treatment and lively discussion in social media, as well as within the more traditional political field and, above all, in the concrete experiences of a population 
of 212 million inhabitants ${ }^{5}$ - and in particular, of that part of the population made up by the 69.3 millions of Brazilians who, living in situations of vulnerability, became recipients of state emergency aid. ${ }^{6}$

The social sciences most certainly demonstrated their vitality during this process - a vitality that found resounding expression in the Bulletin that is the subject of this article. At least insofar as anthropology is concerned, this has involved two concomitant processes. On the one hand, there are analyses that hold firmly to a specific dialogue with the theoretical traditions of the subfields to which they are related. On the other hand, the results of this composition may be considered one of the most palpable expressions of the disciplinary project of anthropology, molded from the variety of resources that the field consolidated over the course of the last century. It is a project based on listening to the populations that are studied, yet also speculating on the limitations that our social arrangements have regarding the integration of these groups and the construction of a future in which there is also a place for them. Perhaps this concomitance is one of the reasons why anthropology has stood out, among the three major areas of the social sciences, in the production of analyses of the pandemic and regarding a post-pandemic future.

The COVID-19 pandemic appears to have produced a new milestone and a new type of reflexive research. This is because the pandemic, as a critical event, has become a total social fact to which not only scholars already devoted to studies in the field of health turned their gaze, but also researchers from many other areas of anthropology. Like a kaleidoscope that at each twist provides a new arrangement of background images and content, studies of the COVID-19 pandemic were made from a wide range of subfields, such as anthropology of work, anthropology of religion, economic anthropology and anthropology of teaching. What we have witnessed is not necessarily the expansion of an anthropology of epidemics, but rather a singular phenomenon, unique in the global history of

5 Data from the IBGE (Instituto Brasileiro de Geografia e Estatística, [2020]).

6 According to the official Brazilian government site, "Emergency Aid payment began in April, in installments of $\mathrm{R} \$ 600$ [per individual] or $\mathrm{R} \$ 1.200$ for mothers providing for their families, totaling five installments. This was followed by an Extended Emergency Aid of R\$ 300, disbursed in up to four installments of $\mathrm{R} \$ 300$ each, or $\mathrm{R} \$ 600$, in the case of mothers who are heads of households" (Governo do Brasil, 2020). 
the discipline, which turned an event that encompasses all of humanity into the starting point for a wide variety of theoretical and thematic analyses.

\section{Social Sciences and the Anthropology of Health}

In 1957, in "The nature and status of medical sociology" (Straus, 1957), a text that was central to debates on the historical process of creating ties between the social sciences and the field of health, Robert Straus argued for a distinction between Sociology in Medicine and Medical Sociology. In Straus's view, the distinction would serve to differentiate two parallel processes, not necessarily convergent, that were taking hold in the United States. On the one hand, sociology in medicine referred to the ever-growing presence of social scientists acting in partnership with researchers from the medical field or even becoming faculty members at medical schools. This process was associated with a movement that could also be observed in England, in large part the result of efforts to bring medicine and behavior studies together, and emerging in the wake of the strengthening of psychology as a disciplinary field. On the other hand, medical sociology referred to an area of growing interest in social science research which turned the field of health into its object of inquiry. Talcott Parsons (1979), Robert Merton, George Reader and Patricia Kendall (1957) and Howard Becker (1967) are among the scholars who did research on related themes during that period.

Certainly, after the publication of Straus's text, the field underwent thorough transformation and his distinction became too limited to describe later stages of the process. Yet we have returned to it here, less in deference to his initial distinction and more to illuminate a tension that runs through contributions to the social sciences of health. We refer to its ability to constitute an integrated body of research and teaching on medical knowledge and forms of health care, its capacity to fashion medicine, health care and health policies into research objects.

A similar observation had already been made by Cynthia Sarti (2010) in a text on Brazil in which she goes specifically into the issue of the teaching of medicine, recognizing in the centrality of the concept of alterity (otherness) a key element for understanding the major contributions of this knowledge matrix to teaching in the health field. Otherness, in this case, refers not only 
to native populations or communities who are less integrated into the logics of Western science; it is also an operational category that summarizes the ability of the social sciences to transform medicine itself, and its practices, into research objects. In other words, when it comes to the study of the body, health and illness from the perspective of the social sciences, the research object becomes, directly or indirectly, the scientific field itself, as an institutional space where truths on the body, and on health and illness in the Western world, are produced.

A recent review of literature written by Sônia Maluf, Érica Quinaglia Silva and Marcos Aurélio Silva (2020), entitled "Antropologia da saúde: entre práticas, saberes e políticas" [Anthropology of health: knowledge, practices and policies], makes reference to a significant increase, over the course of the last decade, of anthropologists who teach in programs and department of Public Health, widening the classical exchanges between Western biomedical systems and traditional approaches to curing. Undoubtedly, the rapid response to the pandemic on the part of Brazilian social scientists is also fruit of the expansion of this field of research and interlocution on health, illness and cure.

On the whole, the observations of these authors provide evidence of the double nature of dialogue between health and social sciences, consolidated over the course of the 20th century and having heavy repercussions in Brazil. On the one hand, we witness the growing institutional presence of anthropologists, sociologists and political scientists in teaching departments within health science fields. This presence was reflected in the type of intervention carried out by social scientists during the pandemic, intent as they were on maintaining a dialogue with the medical field while insisting on the importance of the social determinants of health. On the other hand, the above-mentioned authors also cast light on the development and multiplication of perspectives within the social sciences, committed to the epistemic decentering of broader concepts such as body, health, cure and illness. Related to this is the multiplication of specialized sub-fields, marked by specific interests. As Sarti (2010) and Maluf, Silva and Silva (2020) point out, within the field of anthropology this is a highly consolidated process, as evidenced by the forums for debate and regular academic events that go by names such as the anthropology of epidemics, anthropology of death, anthropology of health, anthropology of disabilities, anthropology of sexual and reproductive rights, etc. 


\section{The lingua franca of the pandemic}

Another intersecting characteristic of social scientists' engagement with the pandemic involves the issue of risk, for which we turn to Isabel Carvalho's text, published in September of 2020.

For the time being, within this pandemic calamity, we are able to observe in real time and without historical distancing - that which Seale-Feldman (2020) captured ethnographically during the post-earthquake period in NEPAL, in 2015, and referred to as the work of disaster. It was the notion that a disaster situation creates the context for certain humanitarian policies, mobilizes international agencies, justifies extraordinary public policies and configures disputes for handling ensuing social and public health crises. In the case of the epidemic, particularly in Brazil, in the U.S.A. and, once again, in Byelorussia, we have witnessed the politicization of medical protocol on the part of governments that tend to minimize the seriousness of the disease. In Brazil and in the U.S.A., for example, governments advocated the use of particular medications, going against scientific findings that indicate their dubious efficacy and costly side effects. Nonetheless, if we social scientists are able to describe and opine on the "disaster work" of the present, an analysis of the disaster still remains to be carried out. What we have are many voices speaking out, certainly richer and more multiple that those of past centuries. Yet we are still awaiting the voices of authorship that speak out with deeper and more lasting meanings and messages, transforming the babble into articulated experiences of the pandemic, with the density that this time deserves, and the authorial sensitivity that work on disasters requires. (Carvalho, 2020).

In pondering work "that still has to be done" on the pandemic, the abovecited author also enables us a better understanding of the nature of what has been written thus far, as well as the horizon of that which remains to be realized, even in the face of the dense volume of analyses that have already been produced. Taking this into consideration, we recognize that one of the major contributions of the Social Sciences to this early moment was having demonstrated, as soon as the first cases began to appear in Brazil, that a pandemic 
is not merely the result of a potent and contagious biological agent that puts millions of lives at risk.

These analyses have made it clear that pandemics are also the result of laws, decrees, official pronunciations and press conferences that, little by little, produce classifications and give names to facts that in the past were disconnected, such as "a fish market in a Chinese city", "evangelical pastors in South Korea", "the consumption of wild animals in Asian countries", "a football game in Italy", "a Brazilian tourist in Egypt", "a maid contaminated by employers who returned from recent holidays in Europe". These apparently random facts begin to produce a certain interpretive coherency. This is due to the inclusion of elements that, as we add on new data, produce a sort of pandemic lingua franca whose very emergence becomes the object of the attention of social scientists. New terms come into use, such as"flattening the curve", "SARS", "confinement", “COVID-19", "Wuhan", "World Health Organization", "vaccine", a vocabulary that has been made ordinary and commonplace by the media.

Thus, what is always at stake is the idea that the materialization of the pandemic as a fact does not depend solely on the existence of a virus, but is directly related to abilities to order, classify and name this complex set of phenomena that envelop individuals and States.

\section{The place of the State within the pandemic}

It is precisely through this type of formulation that the State emerges as a fundamental agent of pandemic experiences and that, in doing so, becomes a justified focus of the attention of social scientists. Without a State, that is, an entity that constructs a coherent notion and name for the phenomenon, there is no pandemic (Toniol, 2020). Evidently, this does not mean that the devastating biological reality of the virus is being negated, nor does this suggest we embark on the dangerous adventures of conspiracy theories and denialism that have come to be commonplace within WhatsApp groups and other social networks. On the contrary, we seek to reaffirm the complexity of a pandemic that depends not solely on the circulation of a biological agent but on acts that institute and give concreteness to disperse manifestations of a phenomenon, placing it firmly at the center of social life. 
In sum, the social sciences joined public debate in order to draw attention to the political and cultural dimensions of the pandemic. In doing so, they also pointed to the problems that were present in those formulations of public opinion that appealed to a certain fantasy that "the virus would be democratic" or egalitarian in the way it affected individuals. Social scientists demonstrated that it was syndemic (Plitt, 2020), that is, a pandemic that spread more violently through impoverished communities, provoking more deaths among the socially vulnerable. In this regard another of the intersecting characteristics of social scientists' engagement with the pandemic comes to the forefront, the issue of risk. There has been insistence on the recognition of the fact that social vulnerabilities reflect asymmetrically on the ability that social actors have to respond to pandemic risks. Thus, to observe, compute and analyze these asymmetries has been a fundamental theme for the social sciences, within the scenario of current public health, social and economic catastrophe.

The political dimensions of the pandemic have been a running theme throughout the humanities and were, in a certain sense, one of the main responses coming from the texts published in the Bulletin. After the introduction developed above, we are now ready to move on to the central issue of this text: when we take a look at the entire set of articles with which social scientists responded to the pandemic, what do they tell us? What are the themes that are repeated, and the most frequently mobilized premises?

\section{Major themes of the Bulletin}

In a more systematic, yet still provisional sense, we also believe that it is possible to offer another approach to this set of responses, organizing them into five general themes. The themes that we have identified in no way exhaust classificatory possibilities but are meant to aid in providing guidance in the systematization of the pandemic 'info-demic'. Thus, we propose the following categorization:

a) specialized texts, making reference to a subfield of the social sciences which we can identify as anthropology of epidemics, and promoting gazes 
that compare the COVID-19 pandemic to that of other experiences in confronting epidemics (such as AIDS, Zika and Ebola);

b) diagnostic texts that map out the effects of the pandemic on different groups, activities and countries. These texts explore issues emerging from the pandemic, without losing sight of the structural aspects that characterize particular cases;

c) prognostic texts, which examine possibilities for overcoming the pandemic, attempting to foresee the types of societal demands and dilemmas that may emerge from it as well as its transforming effects;

d) accounts of experiences that provide testimony from individual prisms, often written in first person and committed to the description of modes of confronting the pandemic, as well as its daily and subjective effects;

e) methodological texts that address their reflections to the interdisciplinary fields of the social sciences, pondering the possibilities, infeasibilities and transformations in the modes of doing research that the pandemic has produced.

These themes offer us a principle for the organization and comprehension of the structures of argument through which the social sciences responded to the pandemic in Brazil, in its early months. In addition to the five categories indicated above, we now turn to examine the themes that were covered in the Bulletin. We introduce and discuss some of the defining characteristics that the Bulletin acquired, using data that help us to situate the initiative and, through it, the more general characteristics of Brazilian social sciences.

In addition to organizing by textual / theoretical approach, we also classify the 150 texts published in the Bulletin into 29 thematic groups which came together in the production of the edited volume Social Scientists and the Coronavirus (Grossi; Toniol, 2020). Not simply sections that enable readers to make their way through the book, divisions serve as indicators of the accent that social scientists gave to their approaches to the first months of the pandemic. While this mode of organization certainly reflects the general vigor of certain fields within the discipline, we also believe that it says something about the thematic options that were privileged during the period.

The table below illustrates our classification system, showing how many texts were published within each category. 


\begin{tabular}{|c|c|}
\hline Eixos temáticos & Número de textos publicados \\
\hline Economia & 9 textos \\
\hline Gênero: violências, raça e trabalho & 8 textos \\
\hline Ciência & 8 textos \\
\hline Conjunturas políticas & 7 textos \\
\hline Religião & 7 textos \\
\hline Educação e ensino a distância & 7 textos \\
\hline Morte & 6 textos \\
\hline Desigualdades sociais & 6 textos \\
\hline Segurança pública, prisão e violências & 6 textos \\
\hline Balanços da pandemia & 6 textos \\
\hline Pandemia situada & 6 textos \\
\hline Internet e conexões & 6 textos \\
\hline Riscos, incertezas e medos & 5 textos \\
\hline Questões do social & 5 textos \\
\hline Políticas públicas & 5 textos \\
\hline Outras epidemias - zika vírus e cólera & 5 textos \\
\hline Meio ambiente & 4 textos \\
\hline Populações do campo e questões rurais & 4 textos \\
\hline Saúde mental & 4 textos \\
\hline Para além das fronteiras brasileiras & 4 textos \\
\hline $\begin{array}{c}\text { Textos de apresentação e balanço } \\
\text { do boletim }\end{array}$ & 4 textos \\
\hline $\begin{array}{l}\text { Impactos em populações tradicionais: } \\
\text { quilombolas, ribeirinhos e ciganos }\end{array}$ & 4 textos \\
\hline Arte e imagens da pandemia & 4 textos \\
\hline Velhice & 4 textos \\
\hline Gestação, partos e nascimentos & 4 textos \\
\hline Deficiências & 4 textos \\
\hline Pandemia e história & 3 textos \\
\hline $\begin{array}{l}\text { Impactos da pandemia sobre populações } \\
\text { indígenas }\end{array}$ & 3 textos \\
\hline Alimentação & 2 textos \\
\hline
\end{tabular}


Although there is a certain equilibrium among topics, we also note that there are six themes that concentrate over $30 \%$ of all texts. The foremost theme is Economics. Within it, there is intense concern over the exacerbation of the social inequalities that characterize the country. Also significant is the debate that took place in Abril of 2020 over the release of an emergency aid that took some time to materialize. It is important to keep the initial moment of the issue in mind, given the fact that the amount of the subsidy was subjected to changes and then ended abruptly at the end of 2020, hitting the most vulnerable segments of the population hard. ${ }^{7}$ A significant characteristic of this thematic axis was that it triggered contributions from all three of the major areas of the social sciences.

Gender and Science are the other two themes that attracted a greater number of articles, a total of eight texts each. Gender was one of the areas that generated considerable production right at the beginning of the period of social isolation. Texts in this group dealt particularly with two specific issues: the rise in cases of domestic violence and increase in inequalities in the sexual division of domestic labor during the pandemic. On the Science theme, debates on the current anti-intellectual wave, disbelief in scientific data and the emergence of anti-vaccine movements in Brazil were constant and intersecting issues throughout the entire period that the project was in effect.

The third set of texts - Political Conjuncture, Religion and Education - were represented by seven articles each. Debates on politics emphasized not only analyses of conjuncture, but also the effects that political decisions made in Brazil at the very beginning of the pandemic had on the epidemiological disaster we continue to suffer. Under the theme of religion, controversies involving resistance to the closing of houses of worship were the privileged topic, alongside description and analysis of the adaptation of religious practices during the stage of greatest social distancing. On the theme of education, a common thread running through all the texts was the debate on the limits, benefits and other issues regarding the changes brought about by distance education, which has since been denominated remote learning. This theme in particular brought together a series of texts with a variety of different perspectives on the

7 The emergency aid that was reduced by $50 \%$ as of September of 2020 was suspended in January and February of 2021. 
matter, thereby serving to situate the debate and provide visibility to divergent positions.

A fourth set of topics containing six articles each dealt were grouped according to the themes Death, Overall Evaluation of the Epidemic, Situated Epidemic, Social Inequality, Public Security, Internet. On the topic of Death, we find articles that ponder the ritualization of death from COVID-19 and the emotional and cultural impact of being unable to bury the dead. Also from the themes of Overall Evaluation and Situated Epidemic emerge a series of approaches to the social, cultural and emotional damage of the increase in contamination and deaths in the country. On the theme Social Inequalities, Economic issues are again brought to the forefront but this time with the specific focus of the effects that the pandemic had on the most vulnerable groups within the population. In the realm of Public Security, pandemic impact is approached both with respect to the changes in the way violence was recorded during the period and the toll that the situation took on the incarcerated, a group that is at extremely high risk and did not receive due attention from the State, given the necropolitical directives of the current administration.

After examining the articles published in the Bulletin, we now turn to their authors, for further reflection on the current characteristics of Brazilian academic production.

\section{Profile of the Bulletin article authors}

The engagement of the social science community that is connected to our national organization, Anpocs, and its speedy reaction in the face of the pandemic were further revealing of the strong interdisciplinarity that reigns within the field.

Over the months that the Bulletin was being published, we were able to observe the astute capacity of the social sciences at the helm of debate on COVID-19, often working in partnership with other disciplinary fields. In fact, $40 \%$ of those who published in the Bulletin were researchers coming from other areas. Another interesting observation is that researchers who had completed their training within the last 15 years were those most engaged in public debate through forms of participation that were not restricted to the most consecrated academic formats, such as journal articles and book chapters. 


\section{Academic titles}

The 150 texts published in the Social Scientists and Coronavirus Bulletin were penned by a total of 193 authors. Most of these authors hold doctoral degrees (145 authors, representing $74.4 \%$ of the total) or are currently working on PhDs (35 authors, representing $17.9 \%$ of the total. The remaining $11.7 \%$ of the texts are distributed between authors holding a Master's Degree (2.1\%), currently working on a Master's Degree (1.5\%), holding 'specialist' titles (0.5\%), undergraduate degrees (1.5\%), and $1 \%$, students currently working on undergraduate degrees or, another $1 \%$ in which authors are represented as research collectives made up of individuals whose names are not given.

The graphs we introduce below demonstrate the diversity of areas of training and engagement of the authors who contribute to the Bulletin, most of whom hold doctorates or are currently working on them.

We observe that the greatest number of authors hold doctorates in Anthropology (fifty with completed degrees and 9 currently working on their PhDs). Sociology appears in second place (27 PhDs and $6 \mathrm{PhD}$ candidates) followed by those who have post-graduate degrees in Social Sciences (24 PhDs and $6 \mathrm{PhD}$ candidates). This is followed by Political Science, with a significantly lesser presence (7 PhDs and $2 \mathrm{PhD}$ candidates) as well as a large number of authors from other areas, with 5 or less PhDs and PhD candidates: Geography, Population Studies, History, Education, Scientific and Technological Policy, Psychology, Public Health, Communications, Environmental Studies, Philosophy, Engineering, Architecture, Law and International Relations.

This data reveals that a) Anthropology prevails as the social science discipline that is most engaged in production on the COVID-19 pandemic and b) social science initiatives in response to the pandemic have been able to attract significant contributions from other disciplines, demonstrating important and growing interdisciplinarity in the field of the social sciences. ${ }^{8}$

8 This data also reveals the crucial engagement of the Anpocs and its ensuing interlocution with other disciplines within the Forum de Ciências Humanas, Sociais Aplicadas, Letras, Linguistica e Artes [Forum of Human Sciences, Applied Social Sciences, Literature, Linguistics and Arts] (FCHCSALLA) during the $2019 / 2020$ period. 
Doutorado

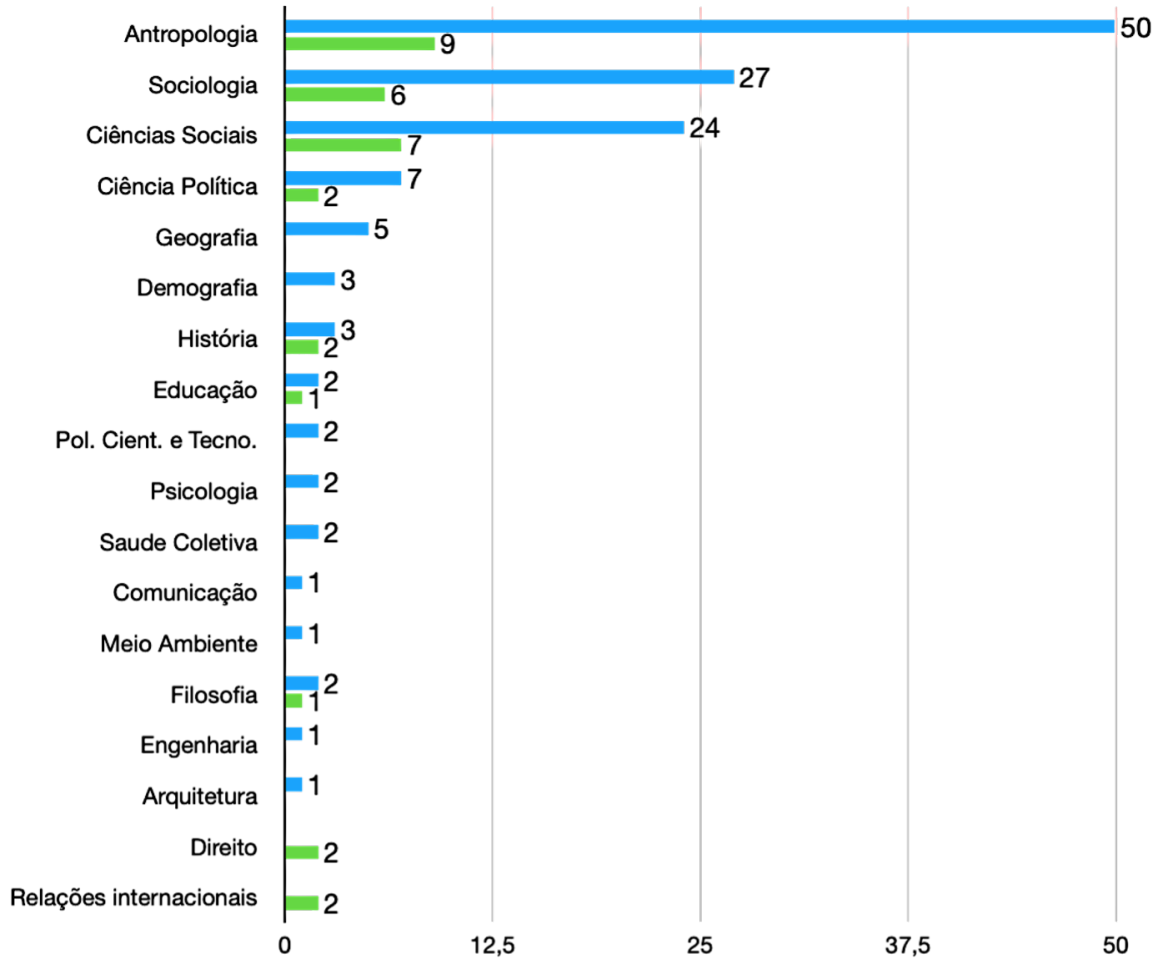

Doutorado em Andamento 50

\section{Areas of involvement}

Regarding the areas of activity of researchers with teaching careers, most of them work in one of the three major areas of Social Sciences, in postgraduate programs in Anthropology (30), Sociology (17), Social Sciences (17), Political Science (6) and International Relations (1). The presence of social scientists working at the interface with the areas of Public Health is also significant (8). There is also an expressive presence of authors who work in the major areas of Humanities - Geography (4), Education (3), History (3), Philosophy (1) - and in the Applied Social Sciences: Social Work (2), Architecture (1), Journalism (1), Communication (1) and Engineering (1). The graph below shows the diversity of areas of activity of Bulletin authors, also providing information on how the 
different social sciences act together and in conjunction with other major areas of knowledge.

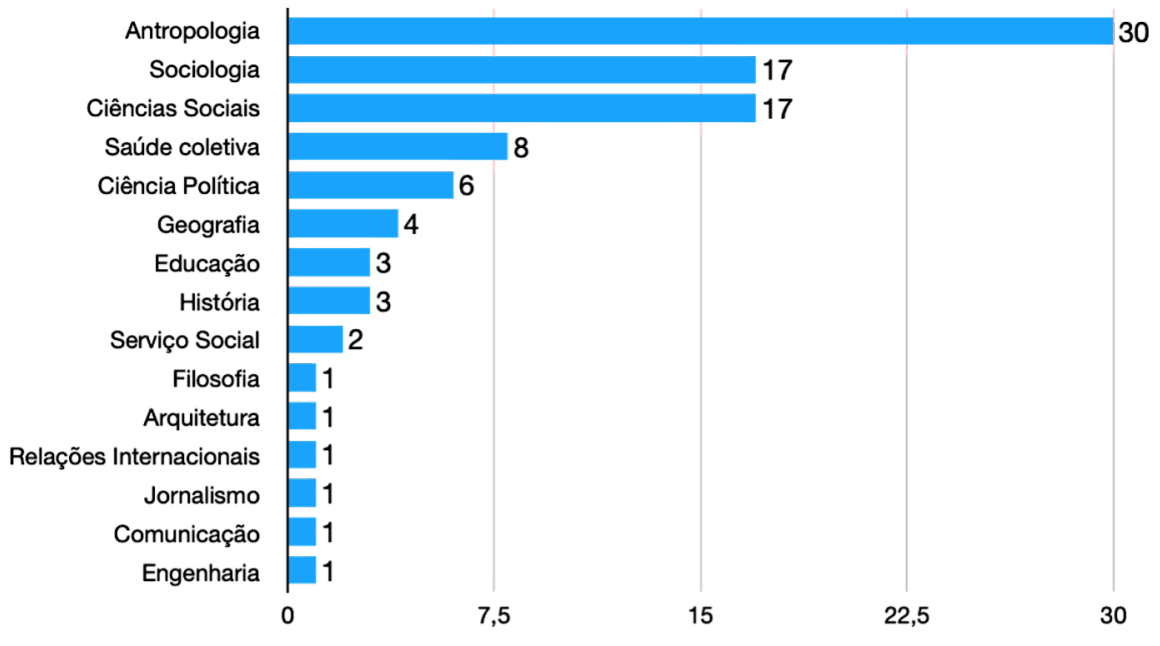

\section{Authors' time [tenure] in their academic fields}

Analysis of authors' trajectories also allows us to understand the expansion of the field of social sciences and to recognize the profound institutional transformation that the area has undergone over the past two decades. Such a transformation can be inferred from a graph providing information on the year in which authors obtained their doctoral degrees.

The graph below shows that $69.1 \%$ of the authors received their degrees in the last 15 years: $25.7 \%$ of the texts were written by doctors who obtained their PhDs in the last 5 years (2016-2020), 27.2\% by doctors who received their diplomas during the previous 5 year period (2011-2015), followed by $16.2 \%$ of texts by authors with older degrees (2006-2010). 
Período de titulação do doutorado

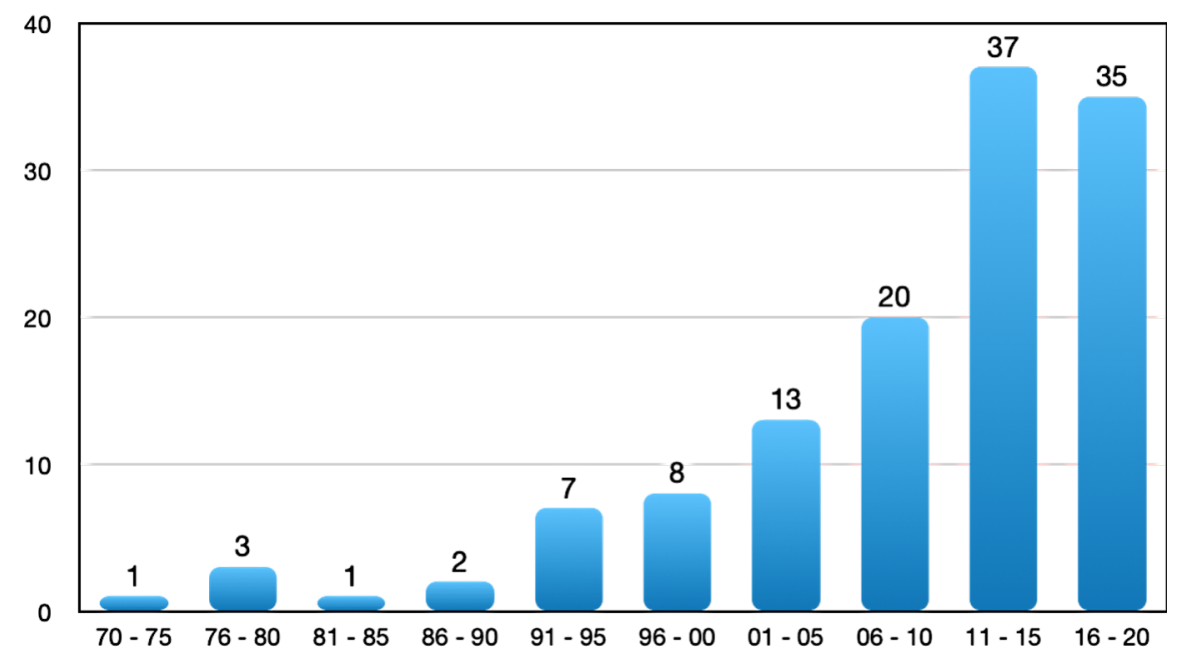

\section{Region of the country ${ }^{9}$}

With regard to the regions where the authors work, we note that the Southeast region, traditional center of the production of knowledge in the Brazilian social sciences, contributed $50 \%$ of all articles published in the Bulletin. This was followed by the South, responsible for $17.9 \%$, and the Northeast, from which came $14.45 \%$ of the total. Nonetheless, there was also a significant presence of authors from the Central West (8.2\%) and the North (5.6\%). Furthermore, contributions were also received from researchers working abroad (Argentina, Portugal and the United States).

9 The importance of examining social scientists' participation by region emanates from Brazil's long history of unequal regional development, and the consequent social, economic and institutional disparities that have traditionally endowed certain regions of the country with a privileged position within the universe of scientific production. 


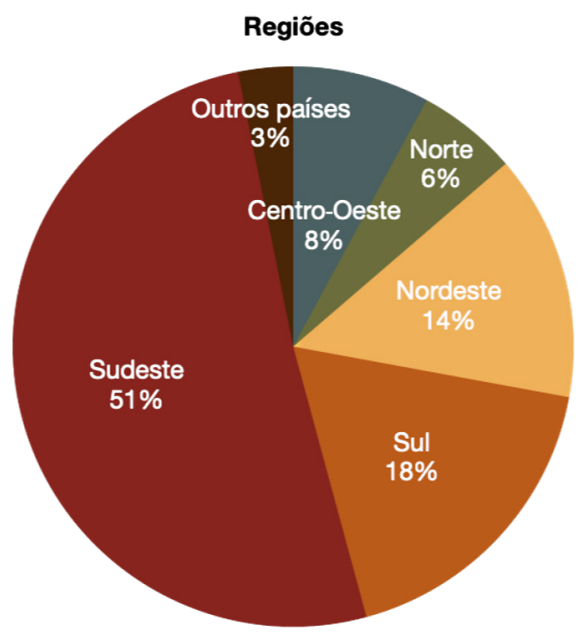

\begin{tabular}{|c|c|c|c|c|c|c|}
\hline Região & Centro-Oeste & Norte & Nordeste & Sul & Sudeste & Outros países \\
\hline $\begin{array}{c}\text { Número } \\
\text { de textos }\end{array}$ & 15 & 12 & 28 & 35 & 97 & 6 \\
\hline
\end{tabular}

The table above reveals another dimension of the transformation of the Brazilian social sciences, the expansion of the regions covered by authors' institutional affiliations. Although participation from the North and Center-East regions is still lower in percentages than other parts of the country, its significance demonstrates the effects of the greater capillarity of the social sciences, the product of public policies for the expansion of higher education in Brazil that were carried out over the first fifteen years of this century.

\section{Authors' institutional affiliations by region}

Graphs by region and institutional participation are introduced below. In the North, with 11 texts originating in institutions from that region, the most expressive institution is the UFPA (state of Pará), responsible for $70 \%$ of all the publications of the region, followed by the UNIR (Rondônia) and UFTO (Tocantins). 


\section{Região Norte - Instituição de vínculo}

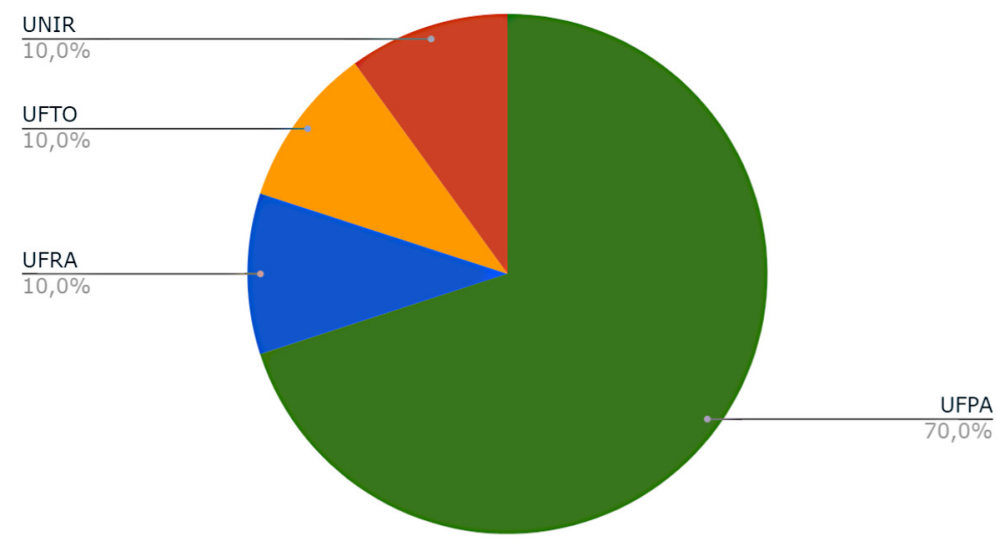

In the Central West, the UnB (Brasília) stands out as the university with the largest number of contributions (66.7\%), followed by UFG (Goiás) with $11.1 \%$, UFGD (Mato Grosso do Sul) and UNEMAT (Mato Grosso), with one published article each (5.6\%). Also noteworthy is the collaboration of authors linked to non-university institutions such as CGEE and IPHAN (institutions based in Brasilia).

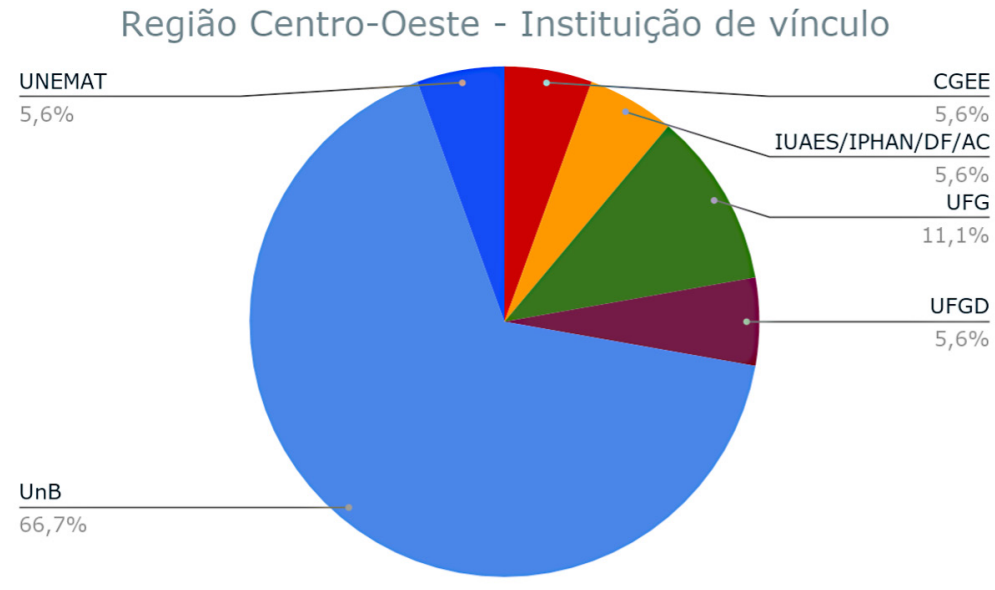


The Northeast region may be noted for its wide variety of participating universities, boasting the presence of social scientists working in universities in all of the states of the region, and diverse in their own right: UFPE (Pernambuco), UFMA (Maranhão), UFPB (Paraíba) with the most texts (16\% each), followed by UNILAB (Bahia and Ceará), UFC (Ceará), UFAL (Alagoas), UFPI (Piauí) and UFS (Sergipe) with $8 \%$ each and UNIVASF (Pernambuco), UECE (Ceará) and UFBA (Bahia) at $4 \%$.

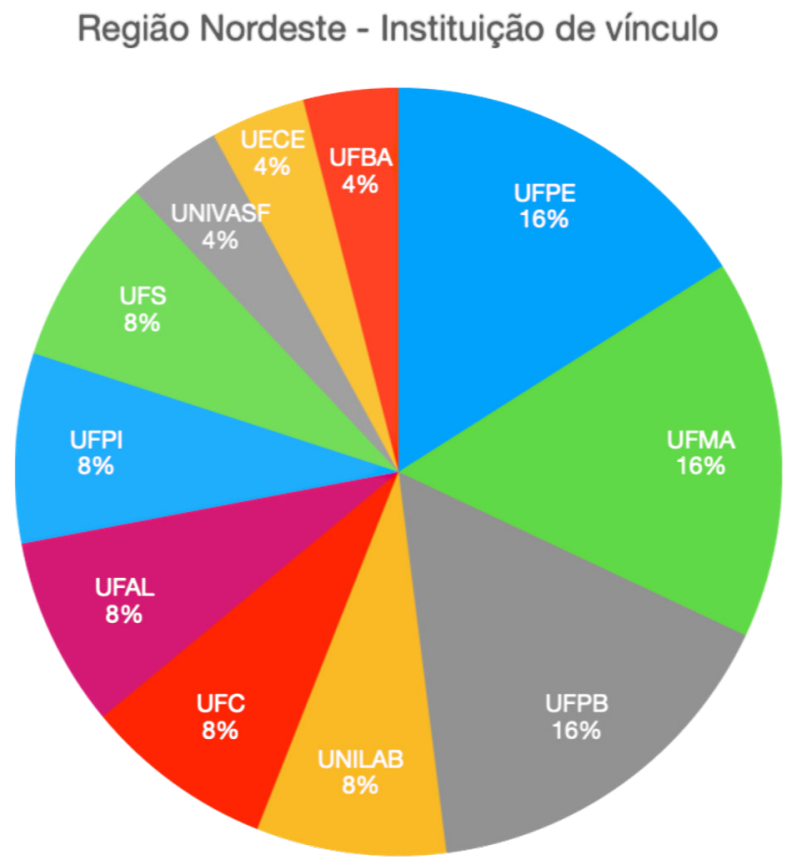

The Southeast is the most diversified region, with 22 institutions producing material for the Bulletin: USP (16.1\%) e UNICAMP (15.1\%), institutions located in the state of São Paulo, contribute the largest number of texts, followed by the UFRJ (6.5\%), Rio de Janeiro, UFMG (5.4\%) - Minas Gerais UFSCAR (5.4\%) UNESP (5.4\%) and UNIFESP (4.6\%) both from the state of São Paulo and finally two other institutions from the state of Rio de Janeiro, UERJ (5.4\%) e UFRRJ (4.3\%). 


\section{Região Sudeste - Instituição de vínculo}

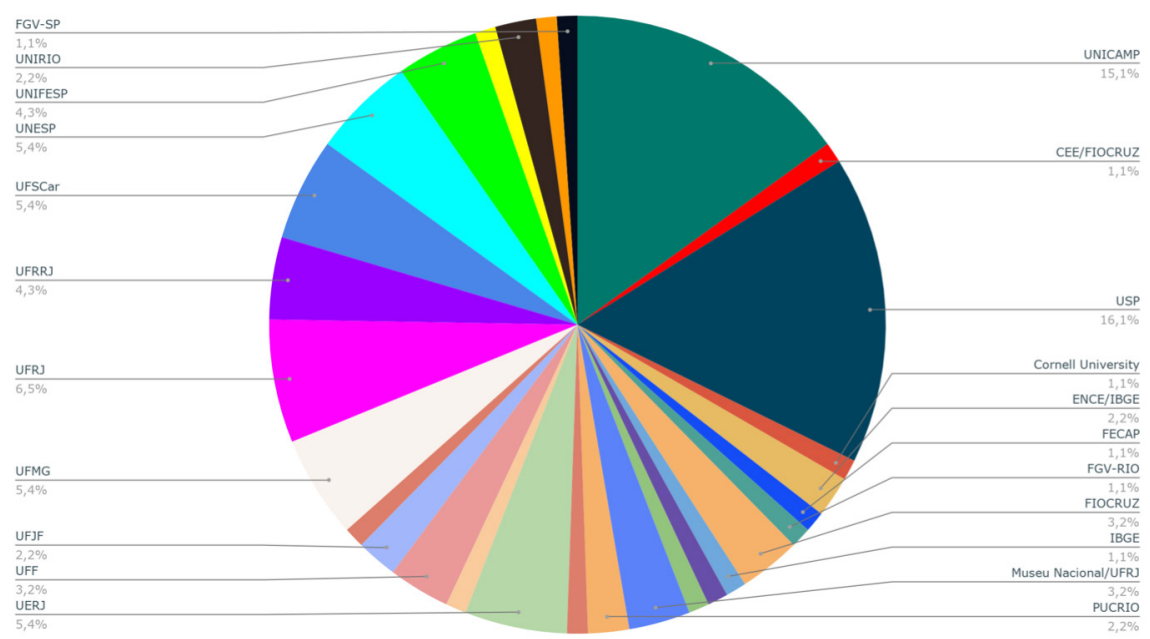

A surprise, in terms of the South, is the expressive presence of the UFRGS (48.5\%) (Rio Grande do Sul), followed by the UFSC (21.2\%) (Santa Catarina) and UFPR (6.1\%) (Paraná). Other participating institutions are the UDESC e UNOESC (Santa Catarina), UNIPAMPA (Rio Grande do Sul) and IFPR (Paraná) (3\% each).

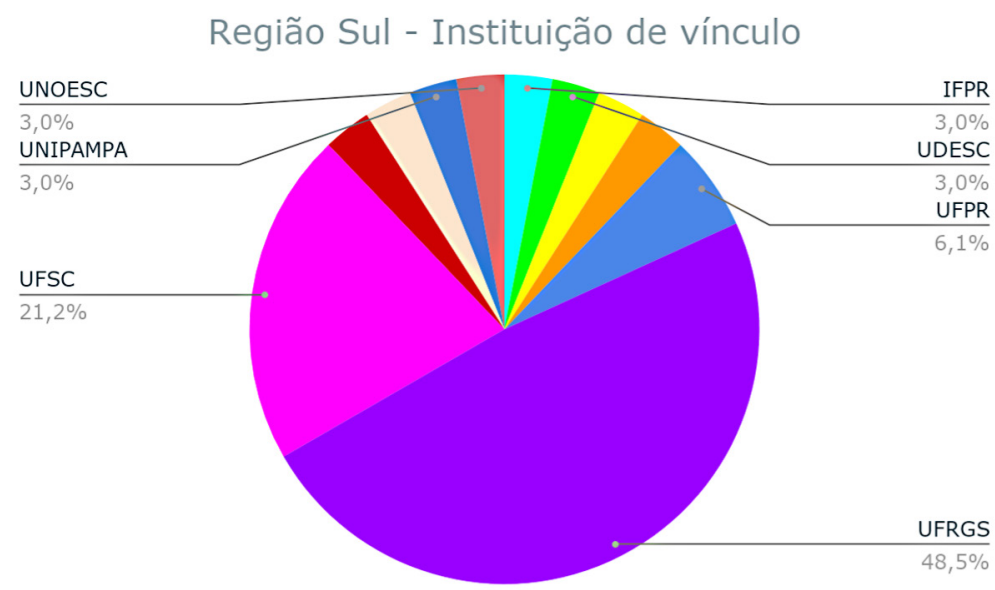




\section{Final considerations}

The Bulletin was produced during the period of social isolation that led all universities and research centers in the country to suspend their physical classes. It filled an important role during the first five months of isolation, nourishing, within social science programs, intense theoretical debate around the impact of the coronavirus. We received countless messages from undergraduate professors from all over the country, expressing how important the Bulletin had been for their class discussions. ${ }^{10}$

Although our initial focus was on the Brazilian public, through international partnerships some of the texts that were originally published in the Bulletin were also translated into Spanish and English, and even disseminated through websites and press channels. In early June we established a partnership with the Brazilian Research and Studies Center at Wurzburg University in Germany. The institution took on the project of translating all Bulletin articles into English. Our CONICET colleagues in Argentina demonstrated similar interest in publishing some of the texts that came out in the Bulletin into Spanish.

We are certain that this initiative contributed to the greater public presence of Brazilian social science research, and for the strengthening of a more agile form of public intervention, albeit not disconnected from the more common formats of academic publication. Furthermore, it seems that the coronavirus pandemic establishes itself as a watershed in terms of the recognition of new forms of intellectual production within the social sciences.

The Bulletin was created on the first Sunday of quarantine. The initiative was an institutional response to the systematic attack on the social sciences that had been occurring in Brazil since the early days of the Bolsonaro presidency, coming most directly from the federal government. At that particular moment, we were galvanized by two actions connected to public policies on education, science and technology: the cuts in post-graduate fellowships

10 In the wake of the Bulletin, the editing team also created a podcast, meant to invert relationships of speech and give interlocutors - rather than researchers - a space in which to narrate the concrete impacts that the pandemic had on their lives. 
coming from the Capes ${ }^{11}$ and the federal government Ordinance $\mathrm{n}^{\circ} 1.122$, dated March 19th, $2020^{12}$ which took the social sciences off the list of MCTI investment priorities,,$^{13}$ actions that are expected to have significant impact on financing opportunities in the Human Sciences as a whole. One of the immediate repercussions was the threat to undergraduate research training that receives support through the "Beginning Researcher" Program (Iniciação Científica - Pibic, CNPq). Both of the above-cited measures took place during the period of social isolation that began in March, at the beginning of the pandemic year of 2020.

Since its conception, the Bulletin was thought up as a way to demonstrate and disseminate how decades of social science research have built up a corpus of knowledge that is also indispensable for our understanding of the pandemic, and most particularly, its social, political, cultural and economic effects on society.

Thus, as we argue, just as the social sciences have demonstrated the political dimensions of the circulation of a devastating biological agent and the modes used to combat it, the assault on our disciplines during this period has also led to a new configuration of scientific policy. The Bulletin itself is a result of an unprecedented alliance between five of the country's major scientific associations, begun at the end of 2018 and known as A4 - Articulação das Ciências Sociais. ${ }^{14}$ In addition to those organizations that were directly involved in its creation, the group soon received the support of others, among which were the Sociedade Brasileira para o Progresso da Ciência (SBPC/SC), the Associação Nacional de Pós-Graduação em Geografia (Anpege), the Associação Nacional de Pós-Graduação em História (Anpuh), the Associação Nacional de

11 Coordenação de Aperfeiçoamento de Pessoal de Nível Superior. Brazil's major financing agency for Post-graduate Education, and institution belonging to the Ministry of Education.

12 Priorities made explicit in its Article 2: Establishment as areas of priority, in terms of projects for research, development and innovation, technological fields that are I - Strategic; II - Skill-providing; III - [in the field of] Production; IV - for Sustainable Development; and V - for Quality of Life.

13 Ministry of Science, Technology and Information, to which the CNPq (Conselho Nacional de Desenvolvimento Científico e Tecnológico) belongs.

14 Or "Interconnected Social Sciences". The A4 was created in October of 2018, during the 42nd Annual Meeting of the Anpocs, by four scientific associations within the field: Anpocs, ABA, $\mathrm{ABCP}$ and SBS. 
Pós-Graduação e Pesquisa em Letras e Linguística (Anpoll) and the Associação Nacional de Pós-Graduação e Pesquisa em Planejamento Urbano e Regional (Anpur) ${ }_{1}^{15}$ the latter working together through the FCHSALLA. ${ }^{16}$ This novel connection has reconfigured the strength of the institutions involved, beyond their specialized academic fields.

In this process, alliances with other areas of the human sciences, and even beyond the latter, have already begun to take shape. This may be explained by the fact that the assault on the humanities has had parallels in other areas of the so-called basic sciences, where responses have come from academics and researchers in biology and life sciences, exact sciences, earth sciences and fields of engineering, under the leadership of the SBPC and the FCHSALLA and scientists from the fields of physics, mathematics and chemistry. In this sense, the defense of science has been renewed, putting social scientists in greater dialogue with other fields and widening the list of allies. The publication of a series of 149 texts through the Social Sciences and Coronavirus Bulletin that we describe and analyze here is also the first result of such a new reconfiguration of forces.

In December of 2020, the initiative that began with the Bulletin gained new shape, as a book made available at no cost through the Anpocs website (Grossi; Toniol, 2020). Divided into thematic sections, it has now been incorporated as compulsory reading in courses taught at a number of Brazilian universities - courses which in and of themselves are remarkable. Fully justified by the health crisis we are submerged in, speculations as to the persistence of such courses within our curriculum are worthwhile. Might this mark a new phase in undergraduate programs in the social sciences? What will the lasting effects of the pandemic on the production and training of new professionals in our areas be like? Answers to these questions will remain for posterity, yet it is essential that, as issues, we already begin to organize ourselves around them.

15 Brazilian Society for Scientific Progress, National Association of Post-Graduate Programs in Geography, National Association of Post-Graduate Programs in History, National Association of Post-Graduate Programs and Research in Literature and Linguistics, National Association of Post-Graduate Programs and Research in Urban and Regional Planning.

16 Fórum de Ciências Humanas, Sociais Aplicadas, Letras, Linguística e Artes. 


\section{References}

BECKER, H. S. History, culture and subjective experience: an exploration of the social bases of drug-induced experiences. Journal of Health and Social Behavior, Thousand Oaks, v. 8, n. 3, p. 163-176, 1967.

BOLETIM CIENTISTAS SOCIAIS E O CORONAVÍRUS. São Paulo: Associação Nacional de Pós-Graduação e Pesquisa em Ciências Sociais, 2020. Available at: http:// anpocs.org/index.php/publicacoes-sp-2056165036/boletim-cientistas-sociais/2325-boletim-semanal. Access: 20 Aug. 2020.

CARVALHO, I. C. de M. Vozes da pandemia: uma história a ser contada. Boletim Cientistas Sociais e o Coronavírus, São Paulo, n. 78, 7 jul. 2020. Available at: http://anpocs. org/index.php/publicacoes-sp-2056165036/boletim-cientistas-sociais/2409-boletim-cientistas-sociais-n-78. Access: 20 Aug. 2020.

DAS, V. Critical events: an anthropological perspective on contemporary India. New Delhi: Oxford University Press, 1995.

ENCONTRO ANUAL ANPOCS,44. [Playlist]. (23 videos). dez. 2020. Published by Anpocs channel. Available at: https://www.youtube.com/playlist?list=PLp6VT-kihN-bvlT00WJkfK6_VbdVaiaMu. Access: 20 Aug. 2020.

GOVERNO DO BRASIL. Auxílio Emergencial já pagou mais de $R \$ 288$ bilhões para garantir proteção social aos brasileiros. Brasília: Governo do Brasil, 21 dez. 2020. Available at: https://www.gov.br/pt-br/noticias/assistencia-social/2020/12/auxilio-emergencial-ja-pagou-mais-de-r-288-bilhoes-para-garantir-protecao-social-aos-brasileiros-1. Access: 20 Aug. 2020.

GROSSI, M. P.; TONIOL, R. (org.). Cientistas sociais e o coronavírus. São Paulo: Anpocs; Florianópolis: Tribo da Ilha, 2020. Available at: http://anpocs.org/index.php/ciencias-sociais/destaques/2458-livro-cientistas-sociais-e-o-coronavirus-ebook-download-gratuito. Access: 20 Dec. 2020.

INSTITUTO BRASILEIRO DE GEOGRAFIA E ESTATÍSTICA. Projeção da população do Brasil e das Unidades da Federação. Brasília: IBGE, [2020]. Available at: https://www. ibge.gov.br/apps/populacao/projecao/. Access: 20 Aug. 2020.

LIMA, N. T. [Conference]. (1 video, 64min). 11 dez. 2020. In: ENCONTRO ANUAL ANPOCS, 44., 2020. Published by Anpocs' channel. Available at: https://www. youtube.com/watch?v=WfAkTYlRpCE\&list=PLp6VT-kihN-bv1T00WJkfK6_ VbdVaiaMu\&index=16. Access: 20 Aug. 2020. 
MALUF, S. W.; SILVA, E. Q.; SILVA, M. A. Antropologia da saúde: entre práticas, saberes e políticas. BIB: Revista Brasileira de Informação Bibliográfica em Ciências Sociais, São Paulo, v. 91, p. 1-38, 2020.

MAUSS, M. Ensaio sobre a dádiva, forma e razão da troca nas sociedades arcaicas. In: MAUSS, M. Sociologia e antropologia: v. 2. São Paulo: EPU: Edusp, 1974. p. 183-314.

MERTON, R. K.; READER, G.; KENDALL, P. L. (ed.). The student-physician: introductory studies in the sociology of medical education. Cambridge: Harvard University Press, 1957.

PARSONS, T. Definitions of health and illness in light of American values and social structure. In: JACO, E. G. (ed.). Patients, physicians and illness. New York: Free Press, 1979. p. 120-144.

PLITT, L. 'Covid-19 não é pandemia, mas sindemia’: o que essa perspectiva científica muda no tratamento. BBC News Brasil, São Paulo, 20 out. 2020. Available at: https:// www.bbc.com/portuguese/internacional-54493785. Access: 20 Oct. 2020.

SARTI, C. Corpo e doença no trânsito de saberes. Revista Brasileira de Ciências Sociais, São Paulo, v. 25, n. 74, p. 77-90, 2010.

STRAUS, R. The nature and status of medical sociology. American Sociological Review, New York, v. 22, n. 2, p. 200-204, 1957.

TONIOL, R. Beyond the virus: there cannot be a pandemic without the State. Ambiente \& Sociedade, São Paulo, v. 23, 2020.

WIEVIORKA, M. [Conference]. (1 video, 48min). 7 dez. 2020. In: ENCONTRO ANUAL ANPOCS, 44., 2020. Published by Anpocs' channel. Available at: https:// www.youtube.com/watch?v=AFki5snJC50\&list=PLp6VT-kihN-bv1T00WJkfK6_ VbdVaiaMu\&index=17. Access: 20 Aug. 2020.

Recebido: 31/08/2020 Aceito: 20/01/2021 | Received: 8/31/2020 Accepted: 1/20/2021 